\title{
Legislative Control of Executive Power in Africa: New Insights
}

By J. B. Ojwang

\section{Introduction}

Constitutional lawyers seem to have left to political science the question: What is so repugnant about power itself, as to justify unending restraint efforts? We should briefly revert to this issue, as a basis for an argument to be formulated from the African perspective of power, and of its control through adopted Western concepts of parliamentarism.

Preston King typifies political power as "the ultimate self-conscious focus of the community's coherence". ${ }^{1}$ It follows that this power exists as a fait accompli and has a vital role in the community. Whether it must be controlled depends on whether it has a mischief potential. ${ }^{2}$ King observes that political leaders, in the exercise of power, will conceive and pursue particular objects, following which they will invite conformity with policy decisions already taken. "Conformity . . . is sometimes reached by threat of force, ... promises of reward; somethimes by lies, sometimes by frank avowal of truth . . $1^{3}$ As Cruise O'Brien remarks, "the person who is applying power, even in the very mild and well accepted form . . . is at least in danger of arrogance and other forms of distortion" ${ }^{4}$

This consideration, which appears to be the basis of the constitutional lawyer's concern, is amply validated by the actuality of arrogance and détournement de pouvoir that must become manifest from this article, which attempts to derive fresh insights ${ }^{5}$ from a Judicial Commission of Inquiry Report recently published in Nairobi, Kenya. ${ }^{6}$

1 P. King, Fear of Power (London: Frank Cass, 1967), p. ix.

2 As to this, Montesquieu had no doubts. He said in De I'esprit des lois (J. P. Mayer and A. P. Kerr (eds.) (1970)), livre XI, Chap. IV, p. 167: "[C]'est une expérience éternelle que tout homme qui a du pouvoir est porté à en abuser; il va jusqu'à ce qu'il trouve des limites".

3 King, op. cit. supra.n.I, p. xiii.

4 Quoted in King, ibid., p. xvi.

5 This article builds on the foundation laid by an earlier one, entitled "Legislative Control of Executive Power in English and French-speaking Africa: A Comparative Perspective", in Public Law, Winter 1981, pp. 511-544.

6 Report of the Judicial Commission Appointed to Inquire into Allegations Involving Charles Mugane Njonjo (Former Minister for Constitutional Affairs and Member of Parliament for Kikuyu Constituency (Nairobi: Government Printer, 1984) (also known as the Miller Report after its Chairman, Hon. Mr. Justice C.H.E. Miller, E.B.S.). 


\section{The existing Relationship between the legislature and the Executive}

I have elsewhere ${ }^{7}$ considered the parliamentary experience in a "New Commonwealth" and in a francophone African country, attempting to identify certain peculiar features of executive power there; and the information thus gained may be taken as a point d'appui from which we may now set out in more affirmatory terms the present state of parliamentary control of government. ${ }^{8}$

Many African countries set off at independence as if they earnestly believed in the virtues of the Western parliamentary system. Hence the provision for such classical parliamentary devices as multi-party systems, the vote of censure, etc. But it soon became clear that a certain political profile, quite the antithesis of the setting at independence, was beginning to emerge. The kind of political stability Africa had opted for, it was becoming evident, did reckon without the role of a plurality of parties; it was a conception of stability built on a fixed foundation, consisting in a President at the helm of a single party - what has aptly been typified as "[un pays] fortement organisé et uni autour d'un chef". ${ }^{9}$

Practice shows that there were two alternatives to that position: the suppression of civilian rule and its substitution with military dictatorship; or the maintenance of a nominal multi-party system that would serve no more than a public relations function. ${ }^{10}$

Assuming that practice could take one of the three positions (rather than some theoretical further alternative), it is arguable that it is the first that merits recognition as the model of "rational" post-independence African tradition: not any of the other two, the one of which implies acceptance of undisguised dictatorship, even as the other entails obvious want of political candour.

But the "rational" position is itself fraught with the danger of abuse of power. Unlike Western countries, where the plenitude of executive powers has undisputed legal authority only in situations of national emergency or other specified types of crisis, ${ }^{11}$ the powers

7 Op. cit. supra n. 5 .

8 It is admitted that this perspective cannot hope to be perfectly representative as it would not accurately describe the position in countries where military rule prevails (e. g. Nigeria, Ghana, Bourkina Fasso, Central African Republic, Liberia, etc.), nor in distinctly revolutionary situations (as in Mozambique or Ethiopia), nor in such countries as South Africa, Libya, etc. - countries with certain distinct local peculiarities.

9 Journal Officiel de la République de Côte d'Ivoire - Débats de L'Assemblée Nationale. September 12, 1966, p. 5 ["Discours du Président élu“].

10 Military regimes abound in Africa (n. 8, supra). As to the alternative of the public-relations plurality of parties, Botswana, Gambia, Senegal and Uganda are notable. In Botswana, the popular example of multiparty democracy, the role of opposition groupings in the constitutional order is strikingly marginal. Seven years ago the late President Khama, in an important parliamentary speech, was reported to have naccused the of ficial Opposition ... of indulging in disruptive left-wing politics"; "he described the Opposition as social malcontents who had contributed nothing to the national welfare but who wanted power at all costs" (emphasis added): Africa Reserach Bulletin: Political, Social and Cultural Series. Vol. 15, No. 11 (15 December 1978), p. 5059.

11 E.C.S. Wade and G. Phillips, Constitutional and Administrative Law. 9th ed. 1977 (by A. W. Bradley), p. 514. 
of the typical African executive remain unaffected at all times, ${ }^{12}$ with grave implications for the constitutional balance of powers. On this point Lanciné Sylla comments thus:

". . . L'hypertrophie de l'exécutif au détriment du législatif, primat de l'exécutif sur le législatif et le judiciaire, . . . concentration du pouvoir, [c'est-à-dire] . . . personnalisation du pouvoir, culte de la personnalité, abandon charismatique des masses à un leader providentiel . . . ${ }^{13}$

The basic reason usually advanced for this concentration is that it is an essential basis for national development - a factor though to be largely absent in Western countries, thus making for a differing political arrangement from that known in the West. "National Development " in this respect normally refers, first, to the process of creating political harmony and of developing a national consciousness; and, secondly, to the efforts to enhance the country's economic activities and improve access to goods and services, in the interest of the citizens. It is thought the constitutional organ in whose domain such major intiatives fall, the executive, ought to have a broad-enough competence for the taking of policy decisions and for implementation of policy. (There are, of course, other justifications, for instance, traditional styles of government which gave broad competence, and sometimes unfettered powers to the leader). ${ }^{14}$

Now in spite of the obvious potential for abuse of powers in their very nature so nebulous, no effective constitutional arrangements exist for their restraint. It has been shown ${ }^{15}$ that traditional control devices such as judiciaries (of the British type), tribunaux administratifs (of the French type), public inquiries, Ombudsmen, etc. are either few and far between, or, even where they exist, are purely symbolic and unequal to the task of bringing under check excessive of executive power. Such formless and ubiquitous powers hardly lend themselves to effective control by procedure-oriented institutions. The legislature alone, of all the power-control devices available, could conceivably offer an appreciable prospect of restraint.

It is now known, however, that what measure of control the legislature could bring to bear, is entirely outside the traditional Western scheme of parliamentary gouvernment. It appears correct to say that the quintessence of the Western scheme consists in the multi-party system, a sociological fact, which sprouts into the [constitutional-legal] parliamentary chamber (thanks to parliamentary elections by-and-large contested on the basis of party sponsorship which is itself governed by a commitment to party "ideology"), and there constitutes the recognised basis of choice in, and orientation of, parliament's constitutional functions (including the function of power restraint). Whether, and to what extent, the Western legislature will bring the executive to account, in the matter of power

12 J. B. Ojwang, "The Nature and Scope of Executive Power in English and French-speaking Africa: A Comparative Perspective", Verfassung und Recht in Ubersee, Vol. 13 (1980, pp. 319-337).

13 L. Sylla, "Crise de Légitimité, Coups d'Etat Militaires: conséquences de la concentration du pouvoir dans L'Afrique Noire contemporaine", Annales de L'Université d'Abidjan (1977) Sér. D, p. 88.

14 I. Hamnett, Chieftainship and Legitimacy (London: Routledge \& Kegan Paul, 1975), pp. 24-44; J. Nyerere, "How Much Power for a Leader", Africa Report (July 1962), p. 5.

15 See supra, n. 5. 
exercised, depends on the party lines represented in the legislature itself. Depending on the opposition parties' attitude towards the conduct of administration, and on whether they are united by a common cause, the ultimate sanction of the vote of no confidence could come into play, and where it is successful, the executive may fall, along with its sponsoring party, on account of abuse of power. ${ }^{16}$

While not suggesting that the problem of power control has disappeared in the Western countries, ${ }^{17}$ one notes that parliament's control function in those countries is more than just theoretical: it is certainly grounded on certain effective devices, supported by available sanctions.

Legislative control of executive power in a one - party state (de jure or de facto), which is the lot of African countries, represents a wholly unorthodox picture and must be understood in that light. The one-party parliament lacks the basic equipment with its constraints and sanctions, for effectively calling the executive to account for its policies, acts or exercises of power. Owing to the monolithic character of such a parliament, there is no active unit within its make-up, with the motivation, initiative, even capacity, to take exception to the government line, let alone articulate such a difference as a policy matter and dress it up in efficacious sanctions.

More importantly, the government line represents the party line, from which the parliamentarian (who must be a member of the party) deviates at this own peril, as he may suffer revocation of his registration as a party member, whith the automatic consequence of loss of the parliamentary seat. ${ }^{18}$ Besides, the vote of no confidence, the traditional parliamentary weapon, becomes impossible to employ in so far as no dissenting opinion, supported by an identifiable group of parliamentarians possessed of a determinative vote, can be articulated and given effect. Thus, even in those countries ${ }^{19}$ that have a provision for the no-confidence vote, in practice, this cannot be exercised and remains lettre morte. (It may be added that, even assuming such provisions could be employed by parliament, technicalities exist which conclusively seal their fate as totally otiose.)

As has been pointed out elsewhere, the purpose of the no-confidence vote in a one-party state is to call upon the electorate, as arbiter, to resolve some major difference between the executive and the legislature:

". . . in practice it may prove impossible to attain this theoretical ragreeableness' within Parliament under single party conditions. [T]he leaders of the executive . . . are also the leaders of the parties. A general election ... must be contested on a [party]

16 J. B. Ojwang, Legislative Control of Executive Powers: A Comparative Study of the British and French-derived Constitutions of Kenya and the Ivory Coast. Ph. D. Dissertation, University of Cambridge (1981), pp- 18-57; 58-100.

17 Quite the contrary: see ibid.

18 E. g., section 34 (d) of the Constitution of Kenya 1969 (as amended) provides that a parliamentary candidate must be "a member of the Kenya African National Union and is nominated by that party in the manner prescribed by or under an Act of Parliament ". Since by s. 2A of the Constitution there can only be one party, any member of the party whose membership thereof is revoked, if he is an M.P., loses his seat and a by-election is held.

19 B. O. Nwabueze, Presidentialism in Commonwealth Africa (London: C. Hurst, 1974), pp. 50-53. 
ticket. If such an election were to take place following a vote of no confidence, the same men who have been denied the confidence of Parliament would be involved in the party work of nominating candidates ... The same men would also determine who contests the presidential election ...; they would effectively be determining which persons will form the new executive ... $4{ }^{20}$

Other restrictions on the vote of no confidence include: a minimum of seven day's notice of the intended motion ("said to be necessary in order to prevent the government being overthrown on a snap vote ${ }^{21}$ - within which time the President could well exercise his constitutional power of dissolution, or the party could take disciplinary action against the movers-to-be of the motion!); large percentages of vote (usually two thirds of the entire voting membership of the Assembly.) in support of the motion; ${ }^{22}$ the President remaining in office all the time while the ensuing elections are still in progress, or when their result is not yet known. ${ }^{23}$ According to Nwabueze, "the main reason why dissolution [in the aftermath of a no-confidence vote] is not likely to be a practical weapon is that [M.P.s], particularly in Africa, stand in great fear on an election, because of its cost and the danger of loss of seat with its perquisites. ${ }^{24} \mathrm{He}$ remarks that M.P.s are thus "quite disposed to agree to any compromise that would avert for them a financial commitment that might prove crippling. ${ }^{25}$ The point, in effect, is that recourse to the ultimate weapon, even where it is provided for, is not likely to be seen by M.P.s as being in their best interest; and on this mundane consideration, that device is of no consequence in the relationship between the two branches of government.

It emerges that institutional factors are at play which render endemic the ineffectiveness of the typical African parliament. This position, which is glaring when compared with the Western experience, must raise one's curiosity as to the experience elsewhere in the Third World.

It may be noted, if only briefly, that there was much greater continuity of institutions ${ }^{26}$ from the colonial to the post-independence era, in India: "The only major break with the colonial past that occurred was in the field of self-government of rural areas. $1{ }^{27}$ The relatively settled traditions of a large bureaucracy, a plurality of political parties, legislative bodies, and a complex set of economic interests have apparently made for a differing or-

20 J. B. Ojwang, "The Residue of Legislative Power in English and French-speaking Africa", International and Comparative Law Quarterly, Vol. 29 (1980), p. 322.

21 Nwabueze, op. cit. supra n. 19, p. 52.

22 Ibid.

23 Ibid.

24 Ibid (emphasis added).

25 Ibid.

26 In most of Africa the participation of the local people in politics and in the institutions of government came precipitously, after decades of a wholly different constitutional profile presided over by nationals of the suzerain state: J. B. Ojwang, "The Residue of Legislative Power in English and French-speaking Africa: A Comparative Study of Kenya and the Ivory Coast", The International and Comparative Law Quarterly. Vol. 29 (1980), pp. 298-304.

27 D. Hiro, Inside India Today (London: Routledge \& Kegan Paul, 1978), p. 49. 
der of political stability, with differing patterns of relationship between major public institutions, from the typical African situation. ${ }^{28}$

Such continuity also marked the development of institutions in the Pacific, ${ }^{29}$ a pattern perhaps further enhanced by the small-scale character of the islands, the singular frailty of their economies, and their consequent dependence on Australia and New Zealand in particular, states that are at the very centre of the Western tradition of governmental organisation.

Additional insights are to be gained from recent developments in Kenya, which suggest that the typical African parliament is potentially less effective still, in the task of power control, owing to certain most remarkable distortions in the usual integrity of public institutions, mainly attributable to informal formations within the executive domain.

\section{The Miller Report: New Insights into the Functioning of the Legislature}

\section{(a) Appointment of the Judicial Commission of Inquiry}

On 26 July, 1983, ${ }^{30}$ President Moi of Kenya, by virtue of powers conferred by the Commissions of Inquiry Act, ${ }^{31}$ appointed a Commission to inquire into the conduct of C. Njonjo, Attorney-General from 1963 to 1980, M.P. and Minister for Constitutional Affairs from 1980 to 1983, in respect of whom accusatory allegations had been made, in the aftermath of political commotions that had just come to a head with an abortive coup attempt on 1. August 1982. A Judicial inquiry into the conduct of one of such a standing, and in a situation so powerfully suggestive of improprieties in the leadership ranks, could hardly fail to lead to instructive relations on the practical aspect of the relationship between the legislature and the executive.

The Commission's terms of reference included the mandate to inquire into the possible misuse by the Minister of his office "as Attorney-General and/or Minister", and into "allegations that he arrogated to himself the duties and powers of the President; that he solicited or received or attempted to receive or offered or made or attempted to make corrupt payments, granted favours or acted to the prejudice of individuals, to seek political suport, to undermine the process of democracy . . " ${ }^{32}$

The Commission, comprising three judges [Miller, J. A. - Chairman, Madan, J. A.

28 Id., pp. 45-51.

29 P.G. Sack, "Constitutionalism and 'Homegrown Constitutions", P. Sack (ed.), Pacific Constitutions (Canberra: ANU Press, 1982), pp. 1-19; C. J. Lynch, "Legislatures in Some Pacific Constitutions", P. Sack (ed.), id., pp. 169-170; Y. P. Ghai, "The Relationship between the Executive and the Legislature: Some Aspects of the Systems of Government in Melanesia", P. Sack (ed.), id., p. 207; N.K.F. O'Neill, "Human Rights in the Hands of the Judges: The Experience in the Pacific Island Nations", Lawasia, Vol. 2, No. 2 (1982-83), pp. 194-219.

30 Gazette Notice No. 2749 of 26 July, 1983.

31 Cap. 102, Laws of Kenya.

32 Report, para I (emphasis added). 
(both judges of some twenty years' standing) and Owuor (Mrs.), J.], set out in their task by adopting trite judicial principles. Relying on, inter alia, Hallett's Commissions and Boards of Inquiry,,$^{33}$ their lordships affirmed that this was "not . . a trial of any individual «; 34 "Our task as we saw it, was to determine whether the allegations specified in the terms of reference have or have not been established. $1{ }^{35}$ In hearing the 62 witnesses produced by assisting counsel, the Commissioners overwhelmingly adhered to the normal court rules: "We have followed the provisions of the Evidence Act (Cap. 80) governing the admission of relevant and hearsay evidence as well as the rules of natural justice in so far as they are not excluded by the nature of the inquiry being a probe. ${ }^{36}$

\section{(b) The Miller Report and the Legislature}

Parliament's charge of power restraint appears to be founded in the belief that each parliamentarian is a man of integrity, guided only by what he conceives to be the best interests of his electors, and of the country at large (of course, taking into account any applicable party commitments). The vitality of the legislature extends beyond the sanctity given by the regulating normative framework, to include the calibre of its members, their autonomy and reliability. ${ }^{37}$

The Miller Report, by contrast, reveals that the typical African parliament may lack a foundation of inner strength, and may be so dangerously exposed to the manoeuvres of ambitious members of the executive who have forged their way into the vital bureaucratic and technical apparatus of the state, that the basic setting no longer favours a meaningful exercise of the power-restraint function. In these circumstances executive power becomes infinitely more difficult to control, as it tends to lose its integrated and "open" character, and instead to incorporate a variegated set of active, essentially self-seeking and unaccountable ingredients vying for the use or abuse of the machinery of public power.

In this respect the Report is to be considered under the following sub-headings: (i) discrediting the "dignified element" as a foundation for parliament's cohesion; (ii) use of political pressure to manipulate election candidature; (iii) employment of financial superiority to neutralise the resoluteness of parliamentarians; (iv) manipulation of civic advanta-

331982 ed.

34 Report, para. 15.

35 Id., para. 14. (On Commissions of Inquiry generally, see Z. Segal, "Tribunals of Inquiry: A British Invention Ignored in Britain", Public Law (1984), pp. 206-214.

36 Id. para. 14. Neither the competence nor integrity nor professional conduct of the Commissioners being the subject of doubt, it must be conceded that the findings in the Report were both accurate and valid, and consequently are a reliable basis for this study. This important aspect, unfortunately, has appeared to disguise itself to Africa Confidential in its issue of January, 1985.

37 Indeed, according to Andre Houriou and Jean Gicquel in their book, Droit Constitutionnel et institutions politiques, 7 th ed. (1980), at pp. 40-41; "La reconnaissance de la contestation manifeste la confiance dans l'individu et entraîne dans son sillage la diversité et la tolérance. La société s'oriente, en conséquence, vers le pluralisme". 
ges to the detriment of certain parliamentarians; (v) distortion of the operation of the state's coercive resources with the aim of penalising certain parliamentarians.

\section{(i) Discrediting the "dignified element" as a foundation for Parliament's Cohesion}

Walter Bagehot argued, with reference to England, that while the daily conduct of government was the function of the "efficient facet" (Prime Minister and Cabinet), the performance of this role would be impaired in the absence of the goodwill and reverence symbolised by the "dignified facet" (Monarchy). ${ }^{38}$ Now in the African context the Presidency, which is the core of the "efficient facet", is also [remarkably] the "dignified facet ",${ }^{39}$ and hence is also the basis of the goodwill and civil obedience that are so crucial to the due operation of all the constitutional organs. The effect of adulterating that climate would most probably be a malfunctioning in the regular parliamentary processes.

The Miller Report reveals the Minister under probe as having set up his own scheme whose ultimate design was to bring him to the presidency. This scheme entailed perversion of parliamentarians, so that they would accord him a semblance of legitimacy in his pursuit. The Minister, while still Attorney-General, ${ }^{40}$ had had "contact men" in Parliament who presumed to know, as early as 1979 , that "he was going to resign as AttorneyGeneral and arrangements had been made for a constituency seat for him and that (he) was going to take over as President later " ${ }^{41}$ Even at that early stage the Minister had been influential enough in Parliament, ${ }^{42}$ to ensure that one of his intermediaries was appointed the Chief Whip, ${ }^{43}$ a crucial position in ensuring homogeneity of orientation amongst M. P.s, especially in a one-party parliament. For a couple of years the Minister and his intermediaries spared no effort in recruiting M. P.s to their "camp". He is reported to have told one of his followers "to tell my friends and [fellow M. P.s] to see where the light was [with the Minister himself] $"{ }^{44} \mathrm{He}$ would occasionally invite an M. P. to see him privately, imploring on "why [the M. P.] was always showing a negative attitude towards him and why he always did not agree with his proposals in Parliament". ${ }^{45}$

During these manoeuvres the Minister would, as a ritual speak depreciatorily of the Head of State. He once said to one M. P.: "At least [the late President] Kenyatta was a President . . But this one [meaning President Moi] does not seem to know what he is doing ". ${ }^{46}$ The M. P. "was shocked", and his bewildered reaction sent the Minister shuffling off to the Front Benches where he should have been in the first place. ${ }^{47}$

38 W. Bagehot, The English Constitution (1963 ed.), p. 82.

39 Ojwang, op. cit. supra n. 16, p. 143.

40 A constitutional office in the public service (s. 109 of the Constitution of Kenya, 1969).

41 Report, para. 69.

42 S. 36 of the Constitution provides: "The Attorney-General shall be an ex officio member of the National Assembly, but he shall not be entitled to vote on any question before the Assembly“.

43 Report, para. 72.

44 Id., para. 105.

45 Id., para. 267; also para. 268.

46 Id., para. 131.

47 Ibid. 
The Minister frequently involved certain M. P.s in interference with state protocol, in a manner that had grave implications for the dignity and authority of the President. The Minister is reported to have "lobbied" with one M. P. "to personally ask . . . the President to remove the Vice-President", attaching to his plea the threat that "if the President did not do so the Kalenjin [the ethnic group from which the President comes] would live to regret it". ${ }^{48}$ In like vein the Minister prated to another M. P. that the new AttorneyGeneral "was messing up the Attorney-General's Office"; the M. P. "should tell the President to combine the two offices of Constitutional Affairs [then headed by the Minister] and the Office of the Attorney-General so that the dignity of the office could be maintained[!] " ${ }^{49}$ The Minister told the same witness he knew "a lot of people were talking a lot of [mischief] about him [the Minister] to the President ... If the President did not stop listening to such characters, one day the he [the President] might fall into trouble.$^{50}$ This secretive assault on the "dignified function" was pursued to the point that the Minister was now contemplating a vote of no confidence against the President (notwithstanding the many odds against this device already considered), the stark unconstitutionality of such a move, initiated by a Minister, regardless! Section 17 of the Constitution binds all Ministers to collective responsibility, on the pain of resignation or dismissal, in case of default. ${ }^{51}$

In 1981 the Minister had told one M. P. that he already had in his "camp" 60 loyal M. P.s, and in 1982 he told the same M. P. that he was seeking a following of 125 M. P.s. To this end he had sent round several of his loyalist M. P.s to enhance the recruiting, if need be, employing all means including promises of reward, threats of evil consequence, money payments, etc. ${ }^{52}$ One M. P. said "he understood the significance of [the parliamentary support sought] . . to be that they would declare a vote of no confidence . . . in the Government of President Moi". ${ }^{53}$

\section{(ii) Use of Political Pressure to Manipulate Election Candidature}

Electoral choice between differing complexions of policy having, in most of Africa, been excluded by the single-party system, the only remaining area of choice - where choice is allowed - is the free competition between candidates. In Kenya, this second order of

48 Id., para. 107.

49 Id., para. 135.

50 Id., para. 139.

51 Id., para. 224.

52 Id., paras. 86-91.

53 Id., para. 109. (In strict terms, the constitution (s. 59 (3)) requires only "the votes of a majority of all members of the Assembly (excluding the ex officio members)", for such a vote to be moved. In an Assembly of 170 voting members, that would have been only 86 M.P.s, although such a bare majority would expose the initiative to a fatal risk of defection). The Commission thus recorded its finding: "We unhesitatingly express our opinion that [the Minister] conducted himself in a manner prejudicial to the Head of State, the image of the President and the constitutionally established Government of the Republic of Kenya" (para. 150). 
electoral choice has been much cultivated since independence, and, in a way, it may be said to constitute the very essence of Kenyan parliamentary democracy. ${ }^{54}$

It is clear from the Miller Report, however, that the said democratic element in the Kenyan parliamentary system could not be taken for granted, as it has been exposed to grave risk by the political manoeuvres already recounted.

Apparently in the quest for a semblance of legitimacy for his manipulations, and as a device for enhancing his standing with a view to a possible no-confidence motion, the Minister had sought to influence electoral choice in various ways.

The Minister himself had resigned his position in the public service to move into a prearranged constituency after it had conveniently been vacated through the resignation of the then sitting M. P., and the Minister's election was without opposition. While it is normal in Kenya to have a couple of uncontested seats at elections, the contrivance in which a popularly elected M. P. casually announces his resignation, to coincide with the resignation of an Attorney-General who then conveniently takes over the constituency, must raise questions as to the genuineness of parliamentary representation.

The Commission accepted the evidence of one witness, to whom the Minister, just before he assumed that rank, had given the ultimatum of choosing between parliamentary candidature, and nearly thirty years of gainful association, as a director, with a private corporation. When he opted for candidature, the Managing Director, on the "Minister's" instructions, invited the witness to sign "a request for his early retirement although he had done nothing to the detriment of the company and his retirement was completely to his disadvantage. He lost his house allowance, free furniture, educational fees for 13 children, medical benefits, and free car and petrol". ${ }^{55}$ The consequence was so agonising and domestically disruptive that the witness "became a sick man as a result ". ${ }^{56} \mathrm{He}$ was also "forced to sell his shares in [a] subsidiary company" ${ }^{57} \mathrm{His}$ proposal to transfer his shares to one of his children was rejected because the "Minister" "did not want to hear about his children". ${ }^{58}$

From these facts it appears probable that the "Minister" was apprehensive of the prospect of the witness becoming an M. P., either because a different person was preferred, or because the witness's contribution in Parliament (to which he was elected against the odds) could not be relied on to advance significantly the "Minister's" cause. The "Mini-

54 J. D. Barkan and J. J. Okumu, "Patrons, machines et élection au Kénya", C.E.A.N., Aux urnes L'Afrique: Elections et pouvoirs en Afrique noire (Paris: Editions A. Pedone, 1978), pp. 119-147. (C. Desouches urges caution of electoral choice in the one-party state: "[Election au suff rage universel direct] . . . qui a toujours été considéré comme un des critères du caractère démocratique d'un régime politique perd . . . une grande part de sa crédibilité dans la mésure ou, de par les techniques électorales adoptées et le rôle prépondérant que jouent les partis, surtout quand il s'agit d'un parti politique unique de fait ou de droit, dans le choix et la révocation des députés, la liberté de choix des électeurs, semble gravement compromise" - C. Desouches, "Les Parlements", G. Conac (dir.), Les institutions constitutionnelles des Etats d'A frique francophone et de la Republique malgache (Paris: Economica, 1979), p. 96.

55 Report, para. 322.

56 Ibid.

57 Id., para. 323.

58 Ibid. 
ster" had indeed told another M. P. "that there were certain [M. P.s] who were not useful to him or to this Government ${ }^{59}$ - and five names were named.

\section{(iii) Employment of Financial Superiority to Neutralise the Resoluteness of M. P.s}

A Cabinet colleague and supporter of the Minister is reported to have gone speechifying in the latter's home district, and had lavished praise thus:

"[The Minister] was a good man, clever, rich and ... had a lot of good leadership in him. The [local] people . . . were very lucky to have someone ... who could do whatever they wanted for them. He appealed to them to give [the Minister] their support because he was a powerful man, one day he might even rule the country . . ${ }^{160}$

The admiration of wealth, influence, and glamour, things without a rational or ethical foundation, is a major hazard to which the institution-building effort is exposed, and in particular in new states that still lack the right atmosphere for stable evolution. If it could be said that the democratically elected legislature was the foremost point in popular choice, the Report has revealed that wealth and influence recently came into play to gravely undermine the cohesion, commitment and integrity of the Kenyan legislature as a crucial constitutional organ.

It was established that when he retired as Attorney-General to become an M. P. and subsequently Minister, the Minister had benefited from certain (at least) censurable arrangements: (a) an agreement had been made between him and an $M$. P. under which the latter resigned his seat; ${ }^{61}(\mathrm{~b})$ the said $\mathrm{M}$. P. had "entered into the agreement as a result of overtures made to him by three of [the Minister's] friends acting as his emissaries "; ;2 (c) the Minister "corruptly made payment of Shs. $160,000[\mathcal{E} 8,000] \ldots$ to [the resigning M. P.] upon his reporting . . . he had handed in his letter of resignation to the then Chief Secretary «; ${ }^{63}(\mathrm{~d})$ "the corrupt payment . . . made . . . was to . . undermine the process of democracy" ${ }^{64}$

The Minister had identified the "unco-operative" M. P. s and he has assigned his agents to win them over. A "difficult" M. P. was so approached, with promises that the Minister would procure his elevation to Assistant Ministerial status. Past successes in such tactics were cited in persuasion. When the overtures were rebuffed, the Minister himself took up the task, inquiring of the M. P. "why your attitude . . is always negative".$^{65}$ The solicitation turned sour with the gaffe of attempting to lodge a wad of currency notes in the M. P.'s pocket, this being repelled amidst scornful yells from a couple of backbench anlookers. ${ }^{66}$

\footnotetext{
59 Id., para. 259.

60 Id., para, 142.

61 Id., para. 258 (i).

62 Id., para. 258 (ii).

63 Id., para. $258(\mathrm{v})$.

64 Id., para. $258(\mathrm{vi})$

65 Id., para. 88.

66 Id., para. 90.
} 
But in such ruses the Minister also had some success. One M. P. was paid on two separate occasions, for undertaking to attract more of his colleagues to the Minister's side. ${ }^{67}$ Another M. P. reportedly received 400,000 Shillings ( $£ 20,000)$ from the Minister, for use in influencing the outcome of civic elections in a crucial, municipality. ${ }^{68}$ The Minister also made a promise (not fulfilled) to make a present of one of his limousines to another M. P. whom he was then wooing. ${ }^{69}$ On yet another occasion, an emissary approached a "difficult" M. P. saying: "[The Minister] wanted to [see him privately] to discuss things and help him financially. $"{ }^{70}$ At that moment a second agent reproved this M. P. for failing to appreciate "that [the Minister] loved him "! ${ }^{71}$ The same M. P. was eventually approached by the Minister who began by vaunting his own wherewithal: "he had helped most of those idiots the M. P.s who had gone to him with their problems but [the interlocutor] with his marxism, had never gone to see him. He could always help . . . sort out some of [the M. P.s] problems. ${ }^{72}$

In 1981 one of the "unco-operative" M. P.s moved a motion concerning land scarcity in one district. He called for Government action to ameliorate economic conditions in the district. The motion came up against the Minister's vehement opposition, and was defeated as a result. Soon thereafter an emissary approached the M. P., saying: "[W]ith this motion of yours, what you needed was to ... see [the Minister] and the problems would be solved. [He] is a very powerful man end if you agree to work with him . . . all your problems will be solved ". ${ }^{73}$

\section{(iv) Manipulation of Civic Advantages to the Detriment of Certain Parliamentarians}

It was established that the Minister, whose portfolio included immigration and police, had assumed personalised control over personnel and machinery involved in the issuance of passports, and the threat, and actural exercise, of withdrawal of passports now became a way of hampering the lawful movement of "difficult" M. P.s.

Just after the disturbances of 1 August, 1982 - the very primum mobile of the inquiry the Minister ordered immigration of ficials to impound the passports of all "unco-operative" M. P.s numbering then, $13 .^{74}$ One such M. P. was directed by local police officers to move from his constituency - home to the capital, where he arrived to learn that immigration officers had gained access to his residence and taken away his passport. ${ }^{75}$ The following month the passport was returned to him, to enable him to attend a parliamentary converence in Italy, subject to the condition that he adopted an accommodating at-

67 Id., paras. 103, 260-264.

68 Id., para. 70.

69 Id., para. 111.

70 Id., para. 121.

71 Ibid.

72 Id., para. 129.

73 Id., para. 115.

74 Id., para. 118.

75 Id., para. 95. 
titude towards the Minister. The Principal Immigration Officer (P. I. O.), also an emissary of the Minister, summoned him on his return. As his attitude to the Minister remained antipathetic, the P.I.O. "became annoyed and told [him] to surrender his passport . . . He never got it back " ${ }^{76}$ Another M. P. also became a victim of this oppressive churlishness, but he stoically dismissed it all: "He has never gone back to collect it as he does not require a passport to go to his constituency "!?7

\section{(v) Distortion of the Operation of the State's Coercive Resources with the Aim of Pena- lising Certain M.P.s}

The Minister's reliance on bureaucratic machinery to debilitate the legislature is already clear from the part played, for instance, by the then Chief Secretary [head of the civil service], or by the immigration officials who operated so as to incommode "unco-operative" M.P.s at every turn. Such arrogation of the state's established machinery reached the apotheosis in the realm of plain coercive power: selective prosecutions, and preventive detention.

Frequently the Minister's agents would warn their victims that if they failed to support the Minister, they "would suffer" ${ }^{78}$ "lose their seats", ${ }^{79}$ would "[not] be safe ${ }^{80}$ - vague but most alarming insinuations. While still Attorney-General, the "Minister" had remonstrated with one back-bencher who, along with some other M.P.s, had frequently applauded the Vice-President when he walked into the chamber. The Minister warned that wif he and other M.P.s did not stop it they could suffer along with others who were opposed to his directives" ${ }^{81}$ This particular M.P. was to be among other "difficult" M.P.s for whom files were opened in the Criminal Investigations Department when subsequently this department became part of the Minister's portfolio. ${ }^{82}$ The object, plainly, was to find the slightest excuse to initiate criminal proceedings, with the threat of loss of seats if sentences exceeding six months should, in the event, be pronounced. ${ }^{83}$ One of the "unco-operative" M.P.s was in 1981 warned by the Minister's agent that he must eschew national politics "which was the main reason for the disagreement with [the Minister] «;84 the threat being that "he would end up in jail", should he not comply. ${ }^{85}$ In 1982 another M.P. proposed a motion urging the prosecution of a leading banker and close ally of the

76 Id., para. 98.

77 Id., para. 118. (The Commission found in both cases that the P.I.O. had acted upon the instructions of his Minister "in order to pressurize the [M.P.s] into joining the Minister's camp" - paras. 309, 310).

78 Report, para. 86.

79 Id., para. 112.

80 Id., para. 116.

81 Id., para. 93.

82 Id., para. 94.

83 Constitution of Kenya, ss. 35 (1) (b) and 39 (1) (b).

84 Report, para. 119.

85 Ibid. (The Minister himself took time to visit this M.P.s constituency to denounce him there: "[T]he Holy Book said cleanliness is next to goldliness but the man [the constituents had] elected . . . was untidy. He did not even shave..." (para. 125). 
Minister, investigations against whom had been terminated when the Minister was still Attorney-General, although inculpatory information could have been produced. ${ }^{86} \mathrm{With}$ out pretending to rely on Section 26 of the Constitution (which gives the Attorney-General a wide discretion in matters of prosecution), the Minister thwarted the proposed motion by simply conveying to the proposer through emissaries that whe would [be] put . . . in trouble ${ }^{487}$ if he went ahead. In 1978 two M.P.s had been prosecuted to conviction, on orders of the Minister who was then Attorney-General, and sentenced to five years's imprisonment each, for the of fence of theft. But as early as 1980, and in complete violation of standing prison rules, the man who had just retired as Attorney-General, and was yet to become an M.P., let alone a Minister, caused prison officials to move the two ex-M.P.s to his home, there to be released after being served with a stern warning in the presence of invited members of the public! ${ }^{88}$ Just after the detention, under the Preservation of Public Security Act, ${ }^{89}$ of one of the "difficult" M.P.s, and before the Commission of Inquiry was appointed, one of the Minister's agents was citing as an example the detained M.P., and demanding of another that he should co-operate with the Minister or else meet with the same fate as had befallen his hapless colleauge. ${ }^{90}$

\section{Conclusion}

This article has sought to elucidate, with the aid of a current illustration, the operative character of the legislature-executive relationship in a representative African country. It emerges that in spite of the glaring abuses of the integrity of parliament, leading members of the executive, by their conduct, acknowledge the importance of the debating chamber, as the foremost council of interlocuteurs valables.

The popular election, the classical democratic base, must be the genesis of parliament's stature in the configuration of principal institutions. Unfortunately, as this article reveals, complete probity cannot be guaranteed in the expression of that fundamental choice. There exists the capacity, within the ranks of the executive, to distort the true character of elections.

Such distortion could extend to other aspects of the legislative entity. Parliament is a conglomeration of separate individuals, who are expected to operate as one solid core, a core of constitutional-legal standing, in the performance of specific tasks, in the interest of the nation at large. It is now clear that constitutional solidarity is liable to subversion from within the ranks of the executive - so much so, indeed, that parliamentary integrity

86 Report, para. 136.

87 Id., para. 137.

88 Id., paras. 276-282.

89 Cap. 57, Laws of Kenya.

90 Report, para. 117. (For detailed discussion on the detention of M.P.s, see J. B. Ojwang, "Parliamentary Privilege in Kenya: The Role of an Imported Constitutional Concept ", University of Tasmania Law Review, Vol. 6 (1978), pp. 78-82. 
is lost, and in its place a docile entity may remain, operating largely at the dictation of a wielder of power.

The role that assertiveness over economic advantages, inter alia (notably the accompanying influence with bureaucratic personnel), has played in subduing individual M.P.s, and thus neutralising the integrity of Parliament as a collective body, may suggest that the typical African country, in so far as it is yet to evolve a stable economic system with common "ethics" of access and participation, is unlikely to support fully the classical parliamentary institution, with autonomy and internal discipline, in its relations with the power-wielding executive organ. ${ }^{91}$ Moreover, the ill-organised and under-developed economic condition must create endless opportunities for abuse by the executive, or by elements therein, thus having a paralysing effect on traditional devices of power control.

It is arguable that this impermanence in the sphere of economic gains has had implications for the possible scope of political discipline, so that the ranks of the executive can so crack that the regular power-wielding entity, the very target of parliamentary restraint, ceases to be identifiable, with the view of deploying regular control devices; instead a variety of orderless units crop up that, because of their centrifugal character, and their unsystematic mode of operation, are hardly amenable to control.

The evident surplusage of executive power that appears to be the rule in most of Africa, thus defies all effective control, by the legislative or any other constitutional organ. 


\title{
The Third World Debt Crisis: Towards New International Standards for Contraction of
} Public Debt

\author{
By Anthony Carty
}

The present law relating to third world debts is primarily a law of private international contracts. This subjects them to national legal systems which are not equipped to consider anthing other than the national interest dimension of the contracts, and, of course their exact terms. So even the banks themselves rarely resort to their chosen jurisdictions.

How is the laywer to react to de facto renegotiation, and, in effect modification of loan agreements? The adjustments made are conditioned by the absence of an effective international monetary legal order. How might such an order be constructed? The debate about the role of the IMF and the World Bank is conducted in purely economic terms, with all the arguments employed heavily contested on all sides.

The degree of disagreement about global economic policy is a reflection of the lack of foundation for global political and legal integration. However one contribution to a public international monetary order would be to appeal to the measure of fairness implicit in the concept of the souvereign equality of states. No state should be expected to accept restrictions upon its constraction of public debt which are not accepted by all states. International and public lawyers should work to encourage the development of standards for the contraction of public debt, from whatever source, which would be common to both developed and developing countries. Private banks should be expected to respect these standards.

\section{Legislative Control Executive Power in Africa: New Insights}

\section{By J. B. Ojwang}

Affirmations of dangers inherent in public are not always attended by concrete examples of practical situations, systematically presented and analysed. This article attempts to illustrate the theoretical proposition that the governmental process is apt to veer towards authoritarianism, in the absence of clear mechanisms of control. The focus is the relationship between the executive and the legislature in the typical African state. The substance of the illustration is drawn from the report of the Miller Commission of Inquiry, which as appointed by President Moi of Kenya in 1983, to investigate inter alia the activities of a former leading Minister, with regard to conduct in the office, to relations with the public, and to various public bodies entrusted with defined obligations. It emerges from the study that, in circumstances of indiscipline, or schism in the ranks of the executive, government malcontents will use a variety of techniques to enfeeble the integrity of 
Parliament, which appears to be seen always as the true base of national interlocuteurs. Parliament's strength is sapped not only in this way; the now ill-defined formation of executive - in the public eye - becomes still more difficult to control. Abuse of power then has the tendency to multiply considerably. It is the recipe for authoritarianism.

\section{Some Thoughts on the Interim Preservation of the Namibian Fishing Heritage}

By D. J. Devine

The raison d'etre of this paper is the fact that no immediate solution of the South West Africa/Namibia political problem appears to be in sight and that the offshore living marine resources of the territory are being depleted in this period of political and legal uncertainty. The principal element which militates against the proper conservation of these resources in the absence of a 200 nautical mile fishing zone opposable to all states and recognized and respected by them. The paper does not address the problem of solving the political problems of the territory but investigates what might be done by way of interim measures to preserve the resources in question on the assumption that the overall political resolution of the territory's status may not be forthcoming for some time. Inadequacies in the existing legal mechanisms are highlighted and a plea is made for co-operation between the various political actors in an effort to preserve such valuable resources. Suggestions are made as to possible characteristics of such co-operation and ideas such as informality of arrangements, provisionality pending final solutions, transparency and consultation are examined. The hope is expressed that practical common sense will overcome a priori political positions in the search for an interim solution to avoid the continuing depletion of the resources. 